\title{
LOCALIZAÇÃO E DELINEAMENTO DE PLUMA DE CONTAMINAÇÃO POR HIDROCARBONETOS ATRAVÉS DOS MÉTODOS GPR E TOMOGRAFIA ELÉTRICA
}

\author{
Rodrigo Alves Ortega \\ Orientador: Dr. Jorge Luís Porsani (IAG-USP) \\ 115 p. - Dissertação (Mestrado) - Defesa 09.02.2007
}

\begin{abstract}
RESUMO. Perfis geofísicos de GPR - Ground Penetrating Radar e Tomografia Elétrica (Eletrorresistividade), bem como coleta de amostras de concentração de Compostos Orgânicos Voláteis - "VOC" foram realizados num centro de abastecimento de locomotivas na região de Paulínia-SP, visando a localização e o delineamento de uma possível pluma de contaminação provocada por derivados de hidrocarboneto (óleo diesel). Foram estudadas duas áreas: "área A" - tanque de armazenamento de combustíveis e "área B" - posto de abastecimento de locomotivas, sendo que estas áreas serão mantidas em sigilo, pois os resultados desta pesquisa referem-se a um projeto comercial. Os resultados geofísicos mostraram regiões anômalas de elevada condutividade elétrica nas seções de caminhamentos elétricos relacionadas com uma zona de sombras, i.e., shadow zonenos perfis GPR que são caracterizadas por uma ausência de reflexão do sinal eletromagnético. Na área "A", as anomalias geofísicas de GPR e eletrorresistividade provavelmente estão relacionadas com as características da geologia local, bem como ao solo saturado, uma vez que os valores das concentrações de VOC são extremamente baixos, indicando ausência de contaminação. Por outro lado, na área "B" as anomalias geofísicas coincidiram com os pontos de amostragem onde os valores de concentração de VOC foram bastante elevados, indicando que esta é uma área com elevado potencial de contaminação por óleo diesel. A integração dos resultados das sondagens de VOC com os resultados dos levantamentos geofísicos (GPR e Eletrorresistividade) foi fundamental para uma melhor caracterização e delineamento da pluma de contaminação nas áreas de estudo, mostrando assim a eficácia dos métodos geofísicos em estudos ambientais.
\end{abstract}

ABSTRACT. Geophysical profiles of GPR (Ground Penetrating Radar) and Electric Tomography (Electric resistivity), as well as Volatile Organic Compounds VOC sampling, had been made in a locomotives fuel supply center located in Paulínia/SP, aiming a localization and delineation for a possible hydrocarbon (diesel oil) contamination plume. Two areas had been studied: Area A fuel tank storage and Area B locomotives fuel supply center. These areas will remain in secrecy because the research is mentioned to a commercial project. The geophysical data related to a shadow zone showed some anomalous high electrical conductivity regions, characterized by absence of electromagnetic wave reflections. In the Area A, the GPR and Electric resistivity anomalies probably related to the geological background as well as saturated soils, once the VOC concentrations are extremely Iow (no contamination, therefore). On the other hand, the Area B showed geophysical anomalies coincident to the high VOC sampling sites (then, potentially oil contaminated areas). In this site, the correlation between the VOC sampling and geophysical data had been essential for the localization and delineation of the hydrocarbon contamination plume, demonstrating the geophysical researches efficiency in environment studies. 